MINERALOGIA, 41, No 1-2: 75-94 (2010)

DOI: $10.2478 / v 10002-010-0006-Z$

www.Mineralogia.pl

MineRALOGICAL SOCIETY OF PolAND

Polskie TOWARZYSTWO MINERALOgICZNE

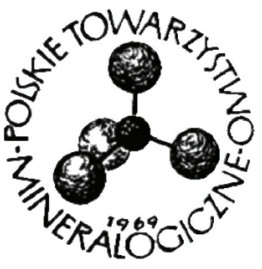

Original paper

\title{
Observations on the effect of proximity to rhyolitic intrusions on Kübler index
}

\author{
Sorcha DISKIN ${ }^{1 *}$, Stephanus H. COETZEE ${ }^{2}$ \\ ${ }^{I}$ Okavango Research Institute, University of Botswana, Private Bag 285 Maun, Botswana \\ ${ }^{2}$ Electron Microscope Unit, University of Botswana, Private Bag 704 Gaborone, Botswana \\ e-mail:diskins@mopipi.ub.bw \\ * Corresponding author
}

Received: August 5, 2010

Received in revised form: March 3, 2011

Accepted: March 10, 2011

Available online: March 31, 2011

Abstract. The Upper Ordovician sedimentary succession of southeast Ireland is riddled with almost synsedimentary igneous intrusions. A study was required to determine any effects of these intrusions on Kübler Index (KI) so that further sampling for a regional study could be undertaken and the results would be unbiased. Sampling was carried out on the low-grade metapelites (Southeast Ireland) around the rhyolitic and doleritic intrusions, which were intruded into the still soft sediment. Clay mineralogy was determined using X-ray diffractometry and KI values were measured; SEM and whole rock elemental analyses were applied to complement the results of the XRD work. KIs immediately around rhyolitic intrusions were observed in all cases to be lower than the regional KI, however this was not seen around doleritic intrusions. SEM work shows illite grain sizes following the $\mathrm{KI}$ trend and $\mathrm{K}_{2} \mathrm{O}$ were noted to be highest where $\mathrm{KI}$ was lowest. Rare earth elements (REEs) show some mobilization which also follows the KI trend. This is considered to be a residual effect of hydrothermal fluids / volatiles hosted by the rhyolites but not encountered in the dolerites. Chlorite crystallinity is not affected as it most likely crystallized after the hydrothermal event. The KI is often used as a proxy for illite crystallinity in studies of low grade metamorphism but is influenced by many parameters and care should be taken when applying this technique to studies of regional metamorphism.

Key-words: Clay, chlorite, dolerite, illite, Kübler Index, rhyolite, sediment chemistry 


\section{Introduction}

In the last four decades, the Kübler Index (KI) has commonly been used as an empirical measure of the changes in the width of illite basal X-ray diffraction (XRD) reflections. The $\mathrm{KI}$ is the full width at half maximum height (FWHM) of the illite $10 \AA \mathrm{X}$-ray diffraction peak, measured on the $<2 \mu \mathrm{m}$ size fraction of an air-dried clay specimen using $\mathrm{CuK} \alpha$ radiation (Kübler 1967, 1968; Dunoyer de Segonzac et al. 1968, Jaboyedoff et al. 2001). The KI is commonly considered to be primarily a function of illite crystallite thickness normal to (001), and this hypothesis has been confirmed by combined transmission electron microscope (TEM) and XRD studies (e.g. Merriman et al. 1990). Measurements of illite "crystallinity" (IC) are widely used as an indicator of incipient metamorphism and are interpreted from the KI. Numerous authors (including Kisch 1987; Frey 1987) have shown how IC increases (i.e. by an increase of crystal ordering and in the size of individual crystallites) as metamorphic grade increases. While temperature is thought to be the main factor affecting crystallite size, other geological parameters are important as well (see Frey 1987 for a review). Due to the relative simplicity of the KI technique it continues to be widely applied to regional surveys of sub-greenschist facies metamorphism in pelitic rocks (e.g. Liu 2003; Crouzet et al. 2007; Kim et al. 2007; Ruiz Cruz 2008).

Arkai (1991) and Arkai and Sadek Ghabrial (1997) have shown that there is a fairly strong positive correlation between crystallinity indices measured on the first two basal reflections of chlorite and those of illite in the $<2 \mu \mathrm{m}$ fractions of representative shale slate - phyllite series from Paleozoic and Mesozoic formations in northeast Hungary. The Arkai Index (AI), similar to KI, expresses the stage the chlorite mineral has reached during its reaction progress, based on the analogies found between the reaction progress smectiteillite-muscovite and smectite-chlorite (Arkai 1991), and is described as the full-width-athalf-maximum values of the first (14- $\AA$ ), and second (7- $\AA$ ) basal reflections of chlorite, measured at conditions similar to KI measurements. AI continues to be used in conjunction with KI in studies of very low grade metamorphism (e.g. Bisevac et al. 2009).

The KI was chosen as a suitable indicator of metamorphic grade in a study of Upper Ordovician low-grade metapelites (Southeast Ireland). However, it is well known that KI is influenced by many parameters (Frey 1987) and must not be overinterpreted (e.g. Guggenheim et al. 2002; Jaboyedoff et al. 2001; Battaglia et al. 2004). These metapelites are intruded by many contemporaneous rhyolite and dolerite intrusions; the effect of these intrusions on $\mathrm{KI}$ is not established in the literature. Effects of proximity to an igneous intrusion on illite-smectite (I-S) mineralogical variation were described by Nadeau and Reynolds (1981), who found that close to the intrusion the I-S is markedly more ordered than far away from it and that the percentage of illite layers in the I-S close to the intrusion is markedly larger. They noted that the I-S changes from random to ordered interstratification between the $100^{\circ}$ and $150^{\circ} \mathrm{C}$ isotherm at about $5 \mathrm{~km}$ from the intrusive centre. They note that samples near other Tertiary intrusions contained similarly ordered I-S. However all the intrusions described by their work are orders of magnitude larger than the intrusions in the Ordovician rocks of the present study area which is intruded by many 
small rhyolitic and doleritic intrusions, consequently no information was available to indicate how sampling for a regional study should be undertaken in their presence. A study of the change in KI around the many contemporaneous igneous intrusions was carried out in order to see whether these intrusions had any effect on the KI and how far away from the intrusions samples for the regional study needed to be taken. Clay minerals were also examined using SEM techniques to determine clay particle sizes and the chemistry of the clay minerals and the whole rock composition around the intrusions were characterised to see if there were any variations around the intrusions.

\section{Geological setting}

The sequence under consideration is located in southeast Ireland (Fig. 1) and comprises middle to late Ordovician, Duncannon Group (Fig. 2) mudrocks and shales with almost contemporaneous intrusions. The Duncannon Group is mainly Caradoc (Gardiner 1974) in age, although it ranges from lower Ashgill to Llandeillo. The Ordovician sequence exposed along the cliffs between Tramore in the east and Stradbally in the west (Fig. 1) consists of shale dominated sedimentary sequences and is extensively interrupted by minor acidic to intermediate near surface intrusions that together with the Ordovician volcanics of the English Lake District and Wales are believed to have been emplaced in an island arc environment which existed at the margin of the southeast foreland of the Caledonian geosyncline (Downes 1974). The contemporaneity of these intrusions with sedimentation is evidenced by the rounded "blobby" nature of the rhyolites and dolerites that were intruded into soft sediment (personal observation). The intrusions vary in size from dikes of $20 \mathrm{~cm}$ thickness to almost $40 \mathrm{~m}$. The whole sequence has been buried to depths in the order of $5 \mathrm{~km}$ and has experienced Caledonian and Variscan regional deformation (Fritz, Stillman 1996). A review of the geology of south County Waterford may be found in Sleaman and McConnell (1995).

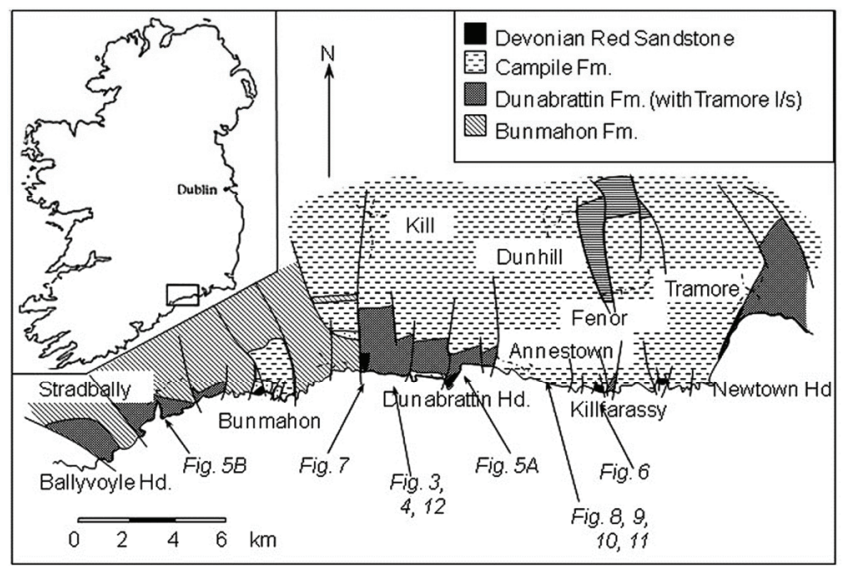

Fig. 1. Simplified geological map of southeast Waterford (redrawn and modified after Sleeman, McConnell 1995). Intrusions not shown due to differences in scale. 


\section{Materials and methods}

Four hundred and fifty two samples were systematically collected from the Caradoc mudrocks/metapelites (Fig. 2) around igneous intrusions of size ranging from $30 \mathrm{~cm}$ to $25 \mathrm{~m}$ from an along strike section between Tramore to Stradbally in County Waterford, Ireland (Fig. 1). Detailed sampling was carried out around these igneous intrusions, samples were taken at intervals of between $5 \mathrm{~cm}$ and $5 \mathrm{~m}$; some samples were also taken from xenoliths of the mudstone within the larger rhyolites.

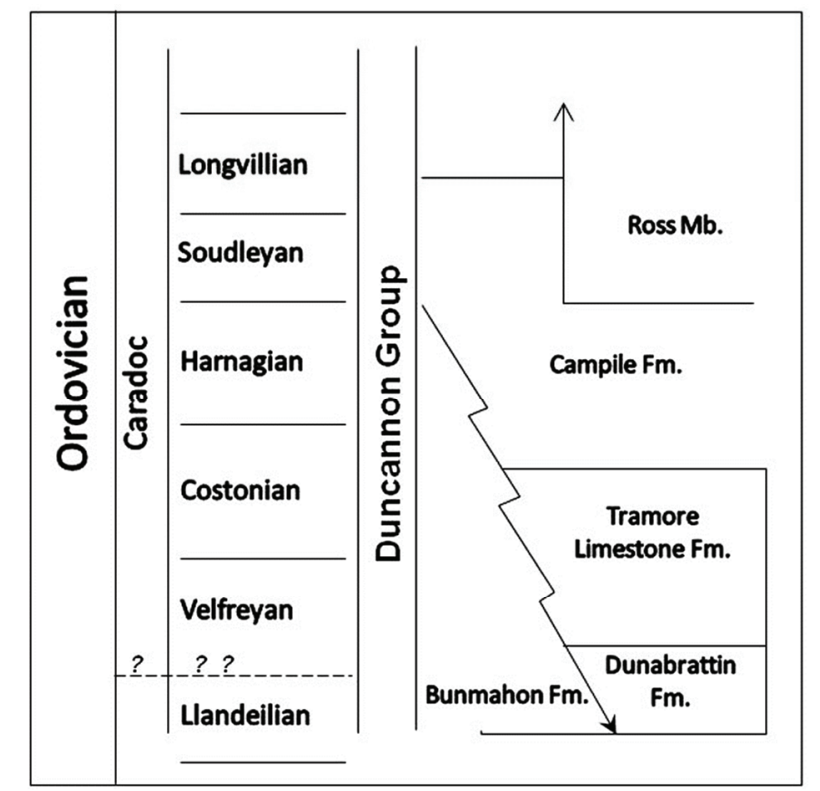

Fig. 2. Stratigraphy of southeast Waterford (adapted from Sleeman, McConnell 1995) showing the formations of the Caradoc Duncannon Group (Ordovician stratigraphic nomenclature is under review by the International Commission on Stratigraphy).

Bunmahon Fm.: dominated by basic to intermediate volcanic rocks, with lavas, hyaloclastites and debris flow deposits together with high level penecontemporaneous basic intrusions emplaced in a marine mudrock succession (Stillman 1978).

Dunabrattin Fm: consists of turbidite dominated sequence of grey laminated shales, siltstones and fine sandstones, showing graded bedding, plane and cross lamination and various bottom structures (Sleeman, McConnell 1995). Tramore Limestone Fm.: comprises an argillaceous basal sequence overlain by calcareous shale and siltstone with a high bioclastic component (Sleeman, McConnell 1995).

Campile Fm.: comprises dark grey to black mudstones, siltstones and shales, which are usually graphitic and may be calcareous (Sleeman, McConnell 1995).

Ross Mbr.: does not crop out along this coast.

Three $\mathrm{kg}$ of each shale sample were collected and all surfaces were cleaned before breaking the samples with a hammer. Samples affected by weathering were identified and 
excluded from this study. In the laboratory, a dried $500 \mathrm{~g}$ subsample was gently broken with an agate mortar and pestle to pass through a 325-mesh sieve. Samples were then prepared for X-ray powder diffraction (XRD) analysis of both illite and chlorite by preparing oriented mounts of clay fractions using the pipette on glass technique of Gibbs (1965), whereby $5 \mathrm{~g}$ of the sieved sample was placed in a $100 \mathrm{ml}$ graduated cylinder with $2 \mathrm{ml}$ of a $10 \%$ sodium hexametaphosphate solution and made up to $100 \mathrm{ml}$ with deionised water shaken vigorously and allowed to stand for 24 hours before being reshaken and allowed stand for a few hours and a $2 \mathrm{ml}$ aliquot containing the $2 \mu \mathrm{m}$ fraction being removed according to Stokes Law. This allows for a sample density of approximately $0.6 \mathrm{mg} / \mathrm{cm}^{2}$. In order to avoid damaging chlorite, no acid dissolution was applied. Air dried (non-glycolated) slides were used following Breitschmid (1982), Blackmore (1995) and other authors who have found that there is little difference between the KI obtained on airdried and glycolated samples at higher crystallinities. However following recommendations of Środon and Eberl (1984) for the standardization of procedures, samples were also glycolated for $8 \mathrm{~h}$ hours at $60^{\circ} \mathrm{C}$. KIs and AIs were determined on a Phillips PW1540 (Trinity College Dublin) or a Phillips PW3710 (University of Botswana) diffractometer using $\mathrm{Cu} \mathrm{K} \alpha$ radiation with an X-ray tube setting of $40 \mathrm{kV}$ and $20 \mathrm{~mA}$. A Ni filter was used as a secondary monochromator. The diffractometer was set up with $1^{\circ}$ divergence slits, a $0.1^{\circ}$ receiving slit, a time constant of 1 second and a range of $1 \times 10^{3}$ counts $/ \mathrm{s}$ as recommended by Kisch (1991); together with a step size of $0.01^{\circ}$. Peak widths were calibrated against Warr \& Rice's IC standards (1994); KI $=(0.10582+1.1316$ Measured $)+$ $.02933) / 1.51156 . \mathrm{KI}$ is expressed in $\Delta^{\circ} 2 \theta \mathrm{CuK} \alpha$. The estimated error of measurement is $\pm 0.01^{\circ} \Delta 2 \theta$.

Material which had passed through the $45 \mu \mathrm{m}$ sieve was mounted onto C-conductive tabs on aluminum stubs for SEM analysis. The samples were given a thin C-coat for HV EDS analysis and a thin Au-coat for photography. Analyses were conducted on a Philips XL30 ESEM equipped with an EDAX EDS system at the University of Botswana.

Chemical analyses of the sieved material $(<45 \mu \mathrm{m})$ were performed at Chemex Laboratories in Canada, using a combination of ICP AES and ICP MS, with samples repeated to ensure analytical consistency. The samples were prepared for major element analysis by fusion dissolution. A similar process was followed by preconcentration by cation exchange for rare earth elements (REEs); this separates the REEs which are present in low (ppm) quantities from the matrix (major elements present in high \% quantities) allowing more accurate measurement. All solutions were measured using calibration curves prepared with international standard rocks materials (SRMs). Precisions and accuracy are estimated to be better than $10 \%$ relative standard deviation on the basis of the results of analyses of the SRMs and study sample replicate analyses. 


\section{Results}

The KIs for a representative selection of igneous intrusions are presented in Table 1 . Figure 3 shows the typical variations of XRD patterns with distance from a rhyolitic intrusion. Small amounts of swelling layers (e.g. Eberl, Velde 1989) may increase the peak breadth, as do interstratifications with other non-illitic layers (Battaglia et al. 2004), therefore the presence of these other materials must be assessed prior to the calculation of KI. The intensity ratio (Ir) of the illites was calculated in each case to assess the proportion of illitic material present (Środon 1984) and generally was found to equal 1, indicating that no expanding clays (illite/smectite) were present. Ir is the peak heights ratio of the 001 and 003 reflections from the air-dry and the glycolated samples:

$$
\mathrm{Ir}=\frac{001 / 003 \text { air-dry }}{001 / 003 \text { ethylene glycol }}
$$

This was verified using Środon's (1984) plot for assessing illitic materials based on 002-003 reflections (Fig. 4).

TABLE 1

Locations of samples for KI and AI with distances towards and away from igneous intrusions from an arbitrary starting point zero

\begin{tabular}{|c|c|c|c|c|c|c|}
\hline & Location & Sample & $\begin{array}{c}\text { Distance } \\
(\mathrm{m})\end{array}$ & $\begin{array}{c}\mathrm{KI} \\
\left({ }^{\circ} \Delta 2 \theta\right)\end{array}$ & Ir & $\begin{array}{c}\mathrm{AI} \\
\left({ }^{\circ} \Delta 2 \theta\right)\end{array}$ \\
\hline \multirow[t]{15}{*}{ Fig. 5A } & Dunabrattin & $95-07 / 26$ & 0 & 0.25 & 1.03 & 0.25 \\
\hline & & $95-07 / 27$ & 10 & 0.25 & 1.04 & 0.25 \\
\hline & & $95-07 / 28$ & 15 & 0.25 & 1.10 & 0.26 \\
\hline & & $95-07 / 29$ & 20 & 0.3 & 1.11 & 0.26 \\
\hline & & $95-07 / 30$ & 25 & 0.29 & 1.07 & 0.25 \\
\hline & & $95-07 / 31$ & 28 & 0.26 & $1.01 \mathrm{q}$ & 0.26 \\
\hline & Rhyolite & $95-07 / 32$ & 29 & 0.26 & 1.12 & 0.25 \\
\hline & Intrusion & $95-07 / 33$ & 30 & 0.25 & 1.02 & 0.26 \\
\hline & & $95-07 / 34$ & 40 & 0.25 & 1.00 & 0.23 \\
\hline & & $95-07 / 35$ & 41 & 0.3 & 1.01 & 0.25 \\
\hline & & $95-07 / 36$ & 42 & 0.34 & 0.99 & 0.25 \\
\hline & & $95-07 / 37$ & 46 & 0.32 & 1.09 & 0.25 \\
\hline & & $95-07 / 38$ & 51 & 0.26 & 1.03 & 0.23 \\
\hline & & $95-07 / 39$ & 62 & 0.25 & 1.01 & 0.25 \\
\hline & & $95-07 / 40$ & 67 & 0.25 & $1.01 \mathrm{q}$ & 0.26 \\
\hline \multirow[t]{13}{*}{ Fig.5B } & Stradbally & $95-10 / 50$ & 0 & 0.19 & 1.06 & 0.19 \\
\hline & & $95-10 / 51$ & 5 & 0.2 & $1.10 \mathrm{q}$ & 0.2 \\
\hline & & $95-10 / 52$ & 10 & 0.19 & 1.03 & 0.18 \\
\hline & & $95-10 / 53$ & 12 & 0.2 & 1.00 & 0.19 \\
\hline & & $95-10 / 54$ & 16 & 0.21 & $0.99 \mathrm{q}$ & 0.18 \\
\hline & & $95-10 / 55$ & 17 & 0.26 & 1.01 & 0.18 \\
\hline & Rhyolite & $95-10 / 55 a$ & 17.5 & 0.2 & 1.01 & 0.18 \\
\hline & Intrusion & $95-10 / 56$ & 17.8 & 0.16 & 1.06 & 0.17 \\
\hline & & $95-10 / 56 a$ & 32 & 0.17 & 1.02 & 0.17 \\
\hline & & $95-10 / 56 b$ & 33 & 0.21 & $1.04 \mathrm{q}$ & 0.18 \\
\hline & & $95-10 / 55 b$ & 35 & 0.24 & 1.03 & 0.18 \\
\hline & & $95-10 / 56$ & 40 & 0.26 & 1.12 & 0.19 \\
\hline & & $95-10 / 57$ & 42 & 0.19 & 1.01 & 0.17 \\
\hline
\end{tabular}




\begin{tabular}{|c|c|c|c|c|c|c|}
\hline & & $95-10 / 57 a$ & 45 & 0.18 & 1.07 & 0.16 \\
\hline & & $95-10 / 57 b$ & 50 & 0.19 & $1.11 \mathrm{q}$ & 0.17 \\
\hline \multirow[t]{6}{*}{ Fig. 5} & Kilfarrassy & $95-04 / 42$ & 4 & 0.26 & $1.16 \mathrm{q}$ & $\mathrm{X}$ \\
\hline & & $95-04 / 43$ & 4.5 & 0.35 & 1.06 & $\mathrm{X}$ \\
\hline & & $95-04 / 44$ & 6.2 & 0.25 & 1.12 & $\mathrm{X}$ \\
\hline & xenolith & $95-04 / 45$ & 8.6 & 0.21 & 0.97 & $\mathrm{X}$ \\
\hline & in rhyolite & $95-04 / 46$ & 13.5 & 0.29 & 1.23 & $\mathrm{X}$ \\
\hline & & $95-04 / 47$ & 14.2 & 0.3 & 1.01 & $\mathrm{X}$ \\
\hline \multirow[t]{10}{*}{ Fig. 6} & Knockmahon & $95-07 / 208$ & 0 & 0.23 & 1.13 & 0.23 \\
\hline & & $95-07 / 209$ & 5 & 0.23 & 1.11 & 0.22 \\
\hline & & $95-07 / 210$ & 10 & 0.24 & 1.03 & 0.23 \\
\hline & Dolerite & $95-07 / 211$ & 15 & 0.25 & 1.15 & 0.23 \\
\hline & Intrusion & $95-07 / 212$ & 17 & 0.17 & 1.02 & 0.17 \\
\hline & & $95-07 / 213$ & 21 & 0.17 & $1.02 \mathrm{q}$ & 0.18 \\
\hline & & $95-07 / 214$ & 23 & 0.21 & 1.04 & 0.19 \\
\hline & & $95-07 / 215$ & 25 & 0.23 & 1.14 & 0.23 \\
\hline & & $95-07 / 216$ & 30 & 0.22 & 1.03 & 0.22 \\
\hline & & $95-07 / 217$ & 35 & 0.23 & 1.01 & 0.22 \\
\hline Fig. 8,9 & Kilfarassy & $95-07 / 219$ & 20 & 0.23 & $1.01 \mathrm{q}$ & $\mathrm{X}$ \\
\hline \multirow{10}{*}{ Fig. 10,11} & & $95-07 / 220$ & 15 & 0.24 & 1.06 & $\mathrm{X}$ \\
\hline & & $95-07 / 221$ & 10 & 0.25 & 1.06 & $\mathrm{X}$ \\
\hline & & $95-07 / 222$ & 5 & 0.23 & 1.09 & $X$ \\
\hline & & $95-07 / 223$ & 2 & 0.24 & 1.11 & $\mathrm{X}$ \\
\hline & & $95-07 / 224$ & 1 & 0.28 & 1.02 & $\mathrm{X}$ \\
\hline & & $95-07 / 225$ & 0.5 & 0.3 & 1.04 & $X$ \\
\hline & & $95-07 / 226$ & 0.2 & 0.31 & 1.03 & $\mathrm{X}$ \\
\hline & & $95-07 / 227$ & 0.15 & 0.25 & 1.14 & $\mathrm{X}$ \\
\hline & Rhyolite & $95-07 / 228$ & 0.1 & 0.24 & 1.02 & $\mathrm{X}$ \\
\hline & Intrusion & $95-07 / 229$ & 0.05 & 0.23 & 1.02 & $\mathrm{X}$ \\
\hline Fig. 10 & Dunabrattin & $95-06 / 27$ & 0 & 0.25 & 1.04 & 0.25 \\
\hline \multirow[t]{13}{*}{ Fig. 3, 4} & & $95-06 / 28$ & 5 & 0.3 & $1.04 \mathrm{q}$ & 0.26 \\
\hline & & $95-06 / 29$ & 10 & 0.29 & 1.09 & 0.26 \\
\hline & & $95-06 / 30$ & 14 & 0.26 & 0.99 & 0.25 \\
\hline & Rhyolite & $95-06 / 31$ & 14.5 & 0.26 & $1.00 \mathrm{q}$ & 0.26 \\
\hline & Intrusion & $95-06 / 32$ & 14.9 & 0.26 & 1.07 & 0.25 \\
\hline & & $95-06 / 33$ & 16.9 & 0.25 & $1.00 \mathrm{q}$ & 0.26 \\
\hline & & $95-06 / 34$ & 17 & 0.25 & $0.97 \mathrm{q}$ & 0.23 \\
\hline & & $95-06 / 35$ & 17.5 & 0.3 & $1.11 \mathrm{q}$ & 0.25 \\
\hline & & $95-06 / 36$ & 18.5 & 0.34 & $1.05 \mathrm{q}$ & 0.25 \\
\hline & & $95-06 / 37$ & 24 & 0.33 & 1.02 & 0.25 \\
\hline & & $95-06 / 38$ & 27 & 0.26 & $1.09 \mathrm{q}$ & 0.24 \\
\hline & & $95-06 / 39$ & 29 & 0.26 & 0.96 & 0.25 \\
\hline & & $95-04 / 48$ & 14.5 & 0.26 & $1.03 \mathrm{q}$ & $\mathrm{X}$ \\
\hline
\end{tabular}

$\mathrm{q}$ - (in the Ir column) indicates that values may be affected by the presence of quartz $\mathrm{X}$ - (in the AI column) indicates that no chlorite was present 


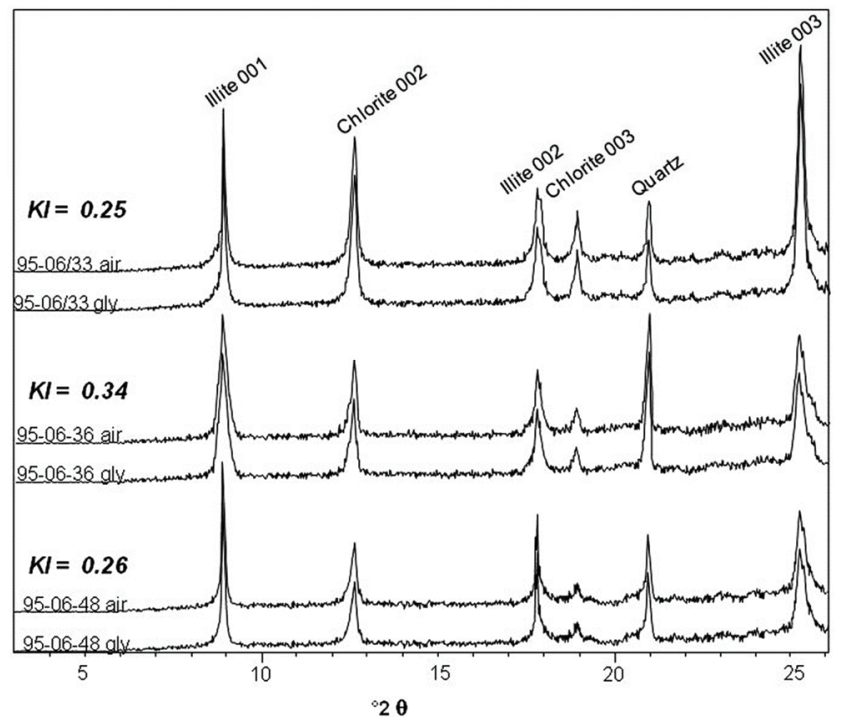

Fig. 3. XRD patterns showing typical variation of mineral composition with distance from a rhyolitic intrusion. Example from Dunabrattin.

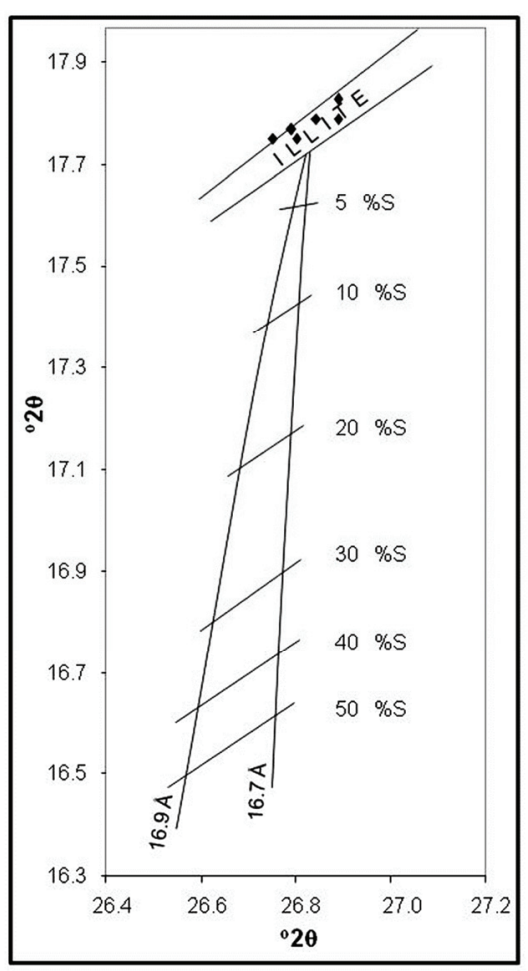

Fig. 4. Plot for determining smectite/illite ratio from 002 and 003 reflections in ordered illite/smectites of diagenetic origin (Środon 1984) with data from clays around a typical rhyolite intrusion (data from samples shown in Figure 10). 
Regionally Kübler indices range between 0.26 and 0.17 with a trend of decreasing KI to the west. However, around rhyolitic igneous intrusions and in "xenoliths" of shale within the rhyolite, KIs as high as 0.4 are noted. For each measurement of KI made in this study, the corresponding measurement of AI was made where possible. Regional KI and AI values correspond quite well in the study area (Diskin 1996) especially in the epizone and anchizone, as has been demonstrated by Àrkai (1991) and Àrkai and Sadek Ghabrial (1997) but will not be further discussed here.

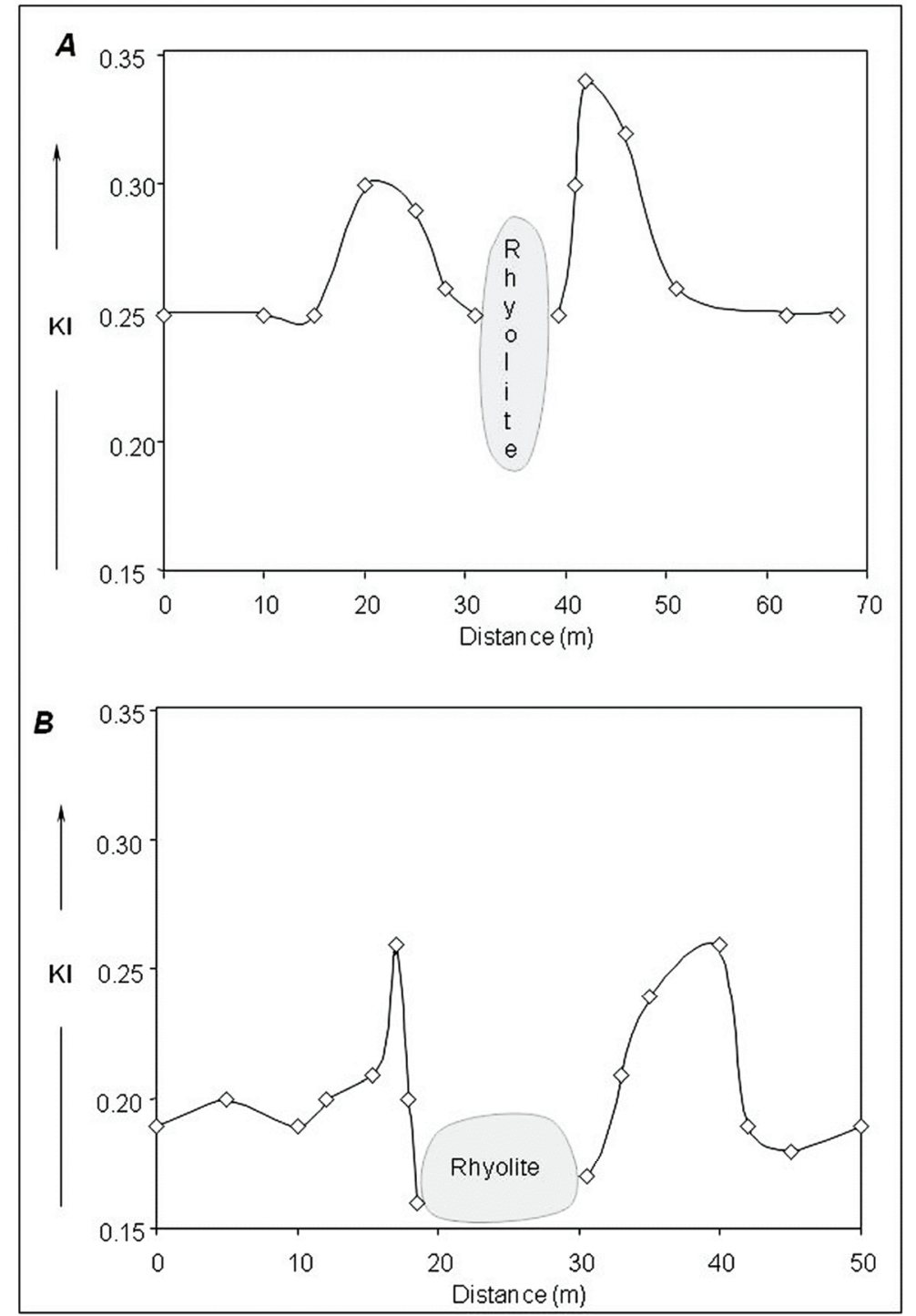

Fig. 5. Plot showing variation of KIs around minor rhyolitic intrusions. 
The KIs around small $(<10 \mathrm{~m}$ ) intrusions were anomalously high (Fig. 5), in contrast to the increase degree of crystallinity expected by Nadeau and Reynolds (1981). The aureole is a few millimeters thick, so the KI might be expected to reflect higher crystallinity near this area (assuming temperature to be the most important factor). This was only seen to be the case just on the shale/intrusion contact, and outside the aureole an apparent increase in $\mathrm{KI}$ is observed. Outside of this extended aureole, the thickness of which is variable, the KI values return to the regional values. This is recognized in all examples to a greater or lesser degree, in most cases by a statistically significant (above the background threshold) number. Anomalous KIs are also observed within the shale xenoliths in the larger rhyolite intrusions (Fig. 6), with the lowest KIs at the very edges and in the centre. One of the highest KIs recorded $\left(0.38 \Delta^{\circ} 2 \theta\right)$ was seen in the centre of a small rhyolite intrusion, where less than one square meter of shale was seen. These anomalies are seen around the rhyolitic intrusions only. Minor dolerites also intrude the sequence. The only effect they seem to have on the surrounding shale is to bake it at the contact (Fig. 7) resulting in a lower KI.

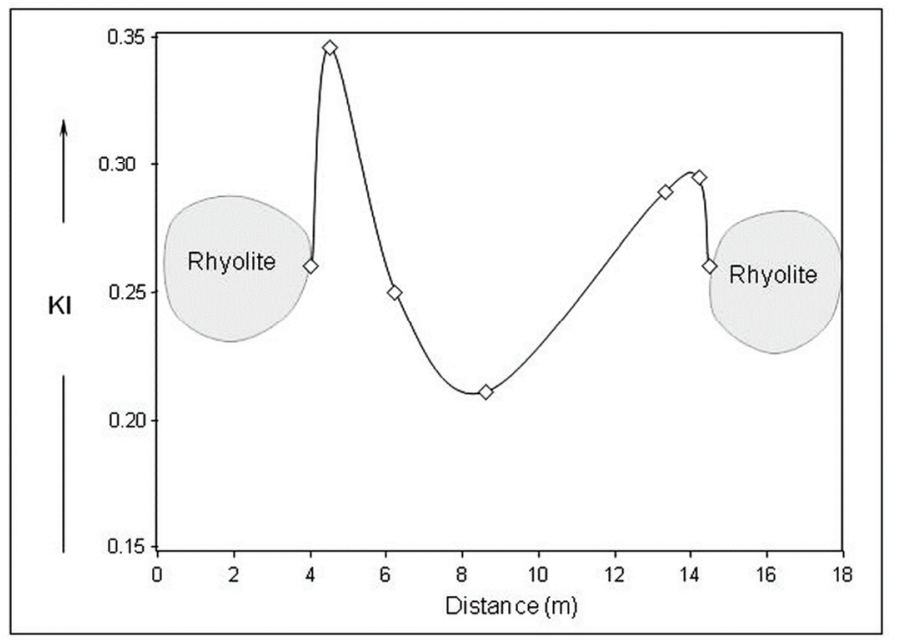

Fig. 6. Plot showing variation of KIs within a shale xenolith in a larger rhyolite body.

The clay minerals were examined using SEM techniques. Figure 8 shows a progression of grain size in the clays around the intrusions. At $5 \mathrm{~cm}$ from the rhyolite intrusion $(43 \mathrm{~cm}$ wide), the grain size is in the order of $2 \mu \mathrm{m}$, at 20 and $50 \mathrm{~cm}$ the grain size drops to below $1 \mu \mathrm{m}$ and at $1 \mathrm{~m}, 5 \mathrm{~m}$ and $20 \mathrm{~m}$ the grain size is seen to be in the order of $2 \mu \mathrm{m}$. These samples were also analysed by SEM-EDAX where major elements including $\mathrm{K}$ as $\mathrm{K}_{2} \mathrm{O}$ were considered (Table 2). Elevated $\mathrm{K}_{2} \mathrm{O}$ was observed in the samples $50-100 \mathrm{~cm}$ from the rhyolite intrusion as shown in Figure 9 (with $\mathrm{K}_{2} \mathrm{O}$ normalised to $\mathrm{Al}_{2} \mathrm{O}_{3}$ to remove variations due to varying quantities of clays present). This coincides with the anomalously high $\mathrm{KI}$ in the shales around the intrusion. 


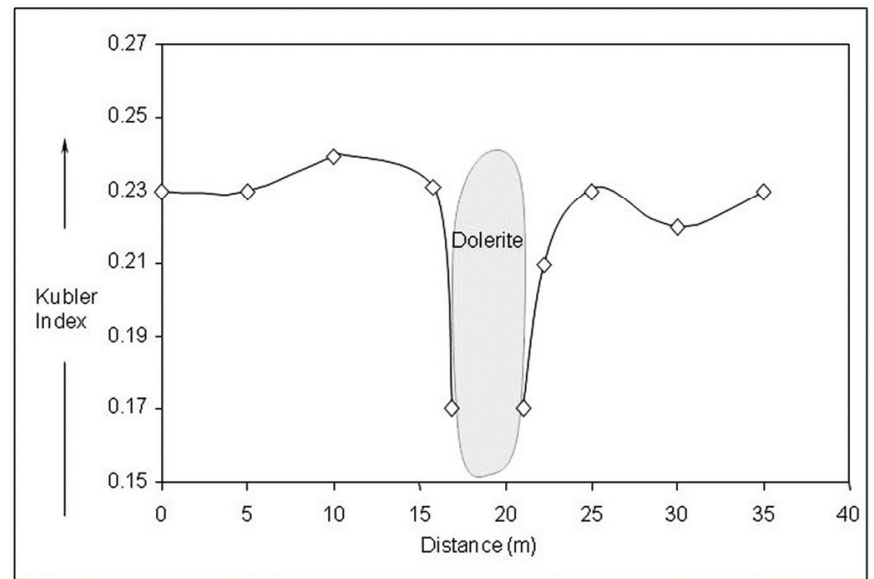

Fig. 7. Plot showing variation of KIs around a dolerite intrusion.

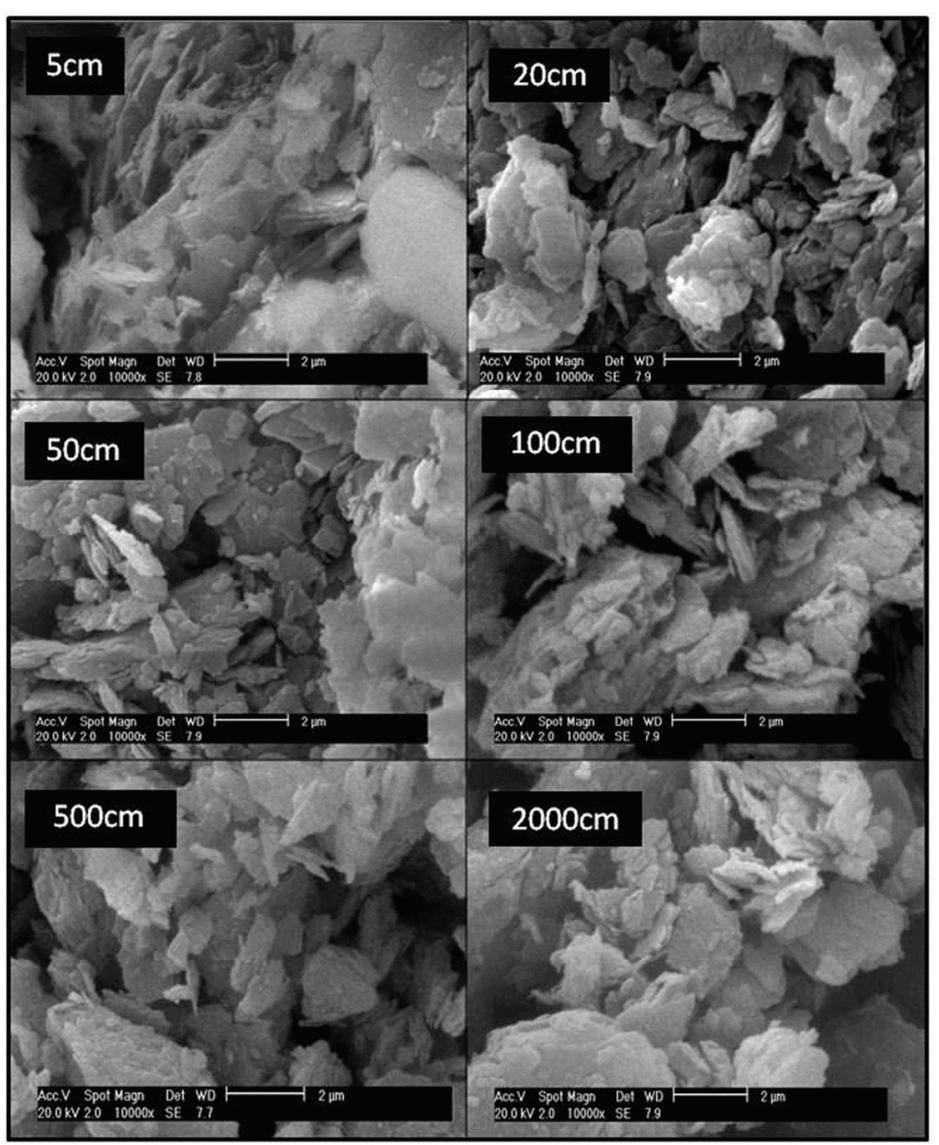

Fig. 8. SEM images showing illite at varying distances from a $43 \mathrm{~cm}$ rhyolite at Kilfarassy. 
Major element concentrations as determined by ICP (whole rock) and EDAX (illite clays)

\begin{tabular}{|c|c|c|c|c|c|c|c|c|c|c|}
\hline & $\begin{array}{l}\text { Distance } \\
(\mathrm{cm})\end{array}$ & $\mathrm{SiO}_{2}$ & $\mathrm{Al}_{2} \mathrm{O}_{3}$ & $\mathrm{Fe}_{2} \mathrm{O}_{3}$ & $\mathrm{CaO}$ & $\mathrm{MgO}$ & $\mathrm{Na}_{2} \mathrm{O}$ & $\mathrm{K}_{2} \mathrm{O}$ & $\mathrm{TiO}_{2}$ & $\begin{array}{c}\text { Total } \\
\text { (except LOI) }\end{array}$ \\
\hline Kilfarassy & 2000 & 59.60 & 19.60 & 7.18 & 0.13 & 1.89 & 0.71 & 3.65 & 0.86 & 93.62 \\
\hline Rhyolite & 1500 & 67.60 & 13.10 & 7.02 & 0.36 & 1.94 & 1.84 & 1.54 & 0.71 & 94.11 \\
\hline \multirow[t]{9}{*}{ ICP } & 1000 & 56.00 & 21.40 & 7.13 & 0.10 & 1.80 & 0.50 & 4.28 & 0.94 & 92.15 \\
\hline & 500 & 54.40 & 22.60 & 6.89 & 0.12 & 1.71 & 0.49 & 4.66 & 1.00 & 91.87 \\
\hline & 200 & 55.30 & 22.20 & 6.93 & 0.14 & 2.11 & 0.40 & 4.56 & 0.97 & 92.61 \\
\hline & 100 & 57.40 & 21.50 & 6.26 & 0.13 & 1.94 & 0.42 & 4.50 & 0.95 & 93.10 \\
\hline & 50 & 57.40 & 21.70 & 5.00 & 0.11 & 1.56 & 0.42 & 4.82 & 0.98 & 91.99 \\
\hline & 20 & 60.65 & 19.65 & 5.15 & 0.16 & 1.71 & 0.66 & 4.15 & 0.95 & 93.06 \\
\hline & 15 & 63.90 & 17.60 & 5.30 & 0.20 & 1.86 & 0.89 & 3.47 & 0.91 & 94.13 \\
\hline & 10 & 63.30 & 17.63 & 5.76 & 0.21 & 2.01 & 0.84 & 3.43 & 0.89 & 94.06 \\
\hline & 5 & 62.70 & 17.65 & 6.21 & 0.22 & 2.16 & 0.78 & 3.39 & 0.87 & 93.98 \\
\hline Bunmahon & 2000 & 59.40 & 17.70 & 11.60 & 0.16 & 3.00 & 0.64 & 2.03 & 0.85 & 95.38 \\
\hline Dolerite & 1500 & 55.20 & 23.40 & 6.73 & 0.10 & 1.51 & 1.15 & 3.49 & 1.04 & 92.62 \\
\hline \multirow[t]{9}{*}{ ICP } & 1000 & 57.20 & 22.10 & 7.00 & 0.09 & 1.73 & 1.02 & 3.15 & 1.02 & 93.31 \\
\hline & 500 & 56.20 & 22.20 & 6.28 & 0.13 & 1.76 & 1.06 & 3.25 & 0.98 & 91.86 \\
\hline & 200 & 51.40 & 19.95 & 6.16 & 0.23 & 1.87 & 1.24 & 3.14 & 1.05 & 85.04 \\
\hline & 100 & 65.65 & 16.20 & 6.82 & 0.15 & 1.91 & 0.78 & 2.55 & 0.93 & 94.97 \\
\hline & 50 & 71.90 & 10.75 & 7.47 & 0.06 & 1.95 & 0.31 & 1.74 & 0.80 & 94.98 \\
\hline & 20 & 54.50 & 20.30 & 9.29 & 0.06 & 2.08 & 0.60 & 3.42 & 1.10 & 91.35 \\
\hline & 15 & 52.40 & 22.57 & 9.38 & 0.07 & 2.22 & 0.68 & 3.90 & 1.23 & 92.45 \\
\hline & 10 & 47.27 & 25.79 & 9.49 & 0.09 & 2.41 & 0.78 & 4.54 & 1.41 & 91.78 \\
\hline & 5 & 45.20 & 27.10 & 9.55 & 0.10 & 2.50 & 0.83 & 4.86 & 1.50 & 91.64 \\
\hline Kilfarassy & 5 & 57.41 & 22.33 & 8.21 & 0.49 & 3.41 & 1.47 & 4.66 & 1.16 & 99.15 \\
\hline Rhyolite & 50 & 56.08 & 25.34 & 6.65 & 0.25 & 2.63 & 1.14 & 5.84 & 1.24 & 99.18 \\
\hline \multirow[t]{4}{*}{ EDAX } & 100 & 56.86 & 24.76 & 7.75 & 0.25 & 2.59 & 0.78 & 5.24 & 1.08 & 99.32 \\
\hline & 500 & 54.73 & 25.34 & 7.93 & 0.10 & 2.62 & 1.11 & 5.06 & 1.05 & 97.93 \\
\hline & 1000 & 55.79 & 24.22 & 8.53 & 0.19 & 2.82 & 1.24 & 4.77 & 1.08 & 98.65 \\
\hline & 2000 & 58.08 & 22.64 & 8.67 & 0.15 & 2.59 & 0.95 & 4.25 & 1.03 & 98.35 \\
\hline Dup Bun & 1000 & 57.20 & 22.08 & 7.04 & 0.10 & 1.79 & 1.03 & 3.20 & 1.01 & 93.45 \\
\hline Dup Kil & 15 & 63.89 & 17.62 & 5.35 & 0.19 & 1.90 & 0.91 & 3.42 & 0.88 & 94.16 \\
\hline OREAS-13P & & 47.40 & 18.95 & 10.85 & 9.61 & 5.67 & 2.52 & 0.53 & 0.54 & 96.07 \\
\hline SY-4 & & 50.70 & 21.81 & 6.25 & 8.05 & 0.51 & 7.23 & 1.64 & 0.29 & 96.48 \\
\hline
\end{tabular}

Result of the whole rock elemental chemistry are presented in Tables 2 (majors) and Table 3 (REEs). Absolute quantities of the major elements are noted to be the same as those obtained using SEM-EDAX and show the same pattern in the $\mathrm{K}_{2} \mathrm{O}$ (Fig. 9B). REEs in sedimentary rocks are dominantly held in the clay fraction. The samples from around the rhyolite intrusions display a chondrite normalised REE pattern typical of post Archaean sediments with LREE enrichment and fairly flat HREE patterns (Fig. 10). LREE enrichment (shown by $\mathrm{La}_{N} / \mathrm{Sm}_{\mathrm{N}}$ ) is noted to be highest on the immediate contact with the rhyolite intrusion, decreasing away from it and then eventually returning to a regional level of enrichment (Fig. 11A). Figure 11B shows the HREE patterns to be a little more unusual, with $\mathrm{Gd}_{\mathrm{N}} / \mathrm{Yb}_{\mathrm{N}}$ increasing in the $20 \mathrm{~cm}$ or so away from the intrusion, before dropping some $1 \mathrm{~m}$ away and then returning to the regional levels. $\mathrm{Eu} / \mathrm{Eu}^{*}$ and $\mathrm{Ce} / \mathrm{Ce}^{*}$ are also affected in that it drops in the first $20 \mathrm{~cm}$ or so and then returns to regional levels quite quickly (Fig. 11C, 11D).These variations in the REE patterns are not noted around the doleritic intrusions. 


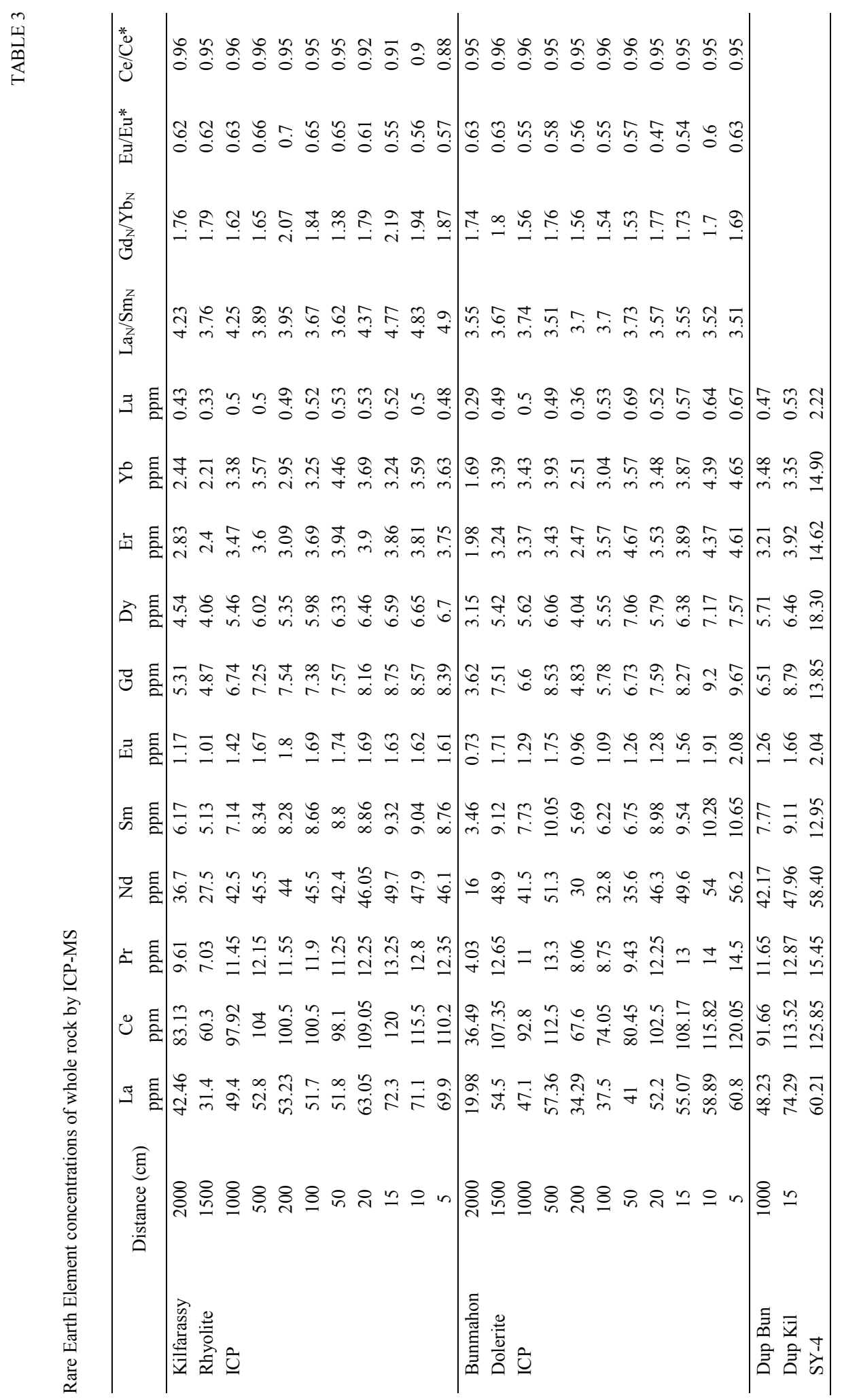




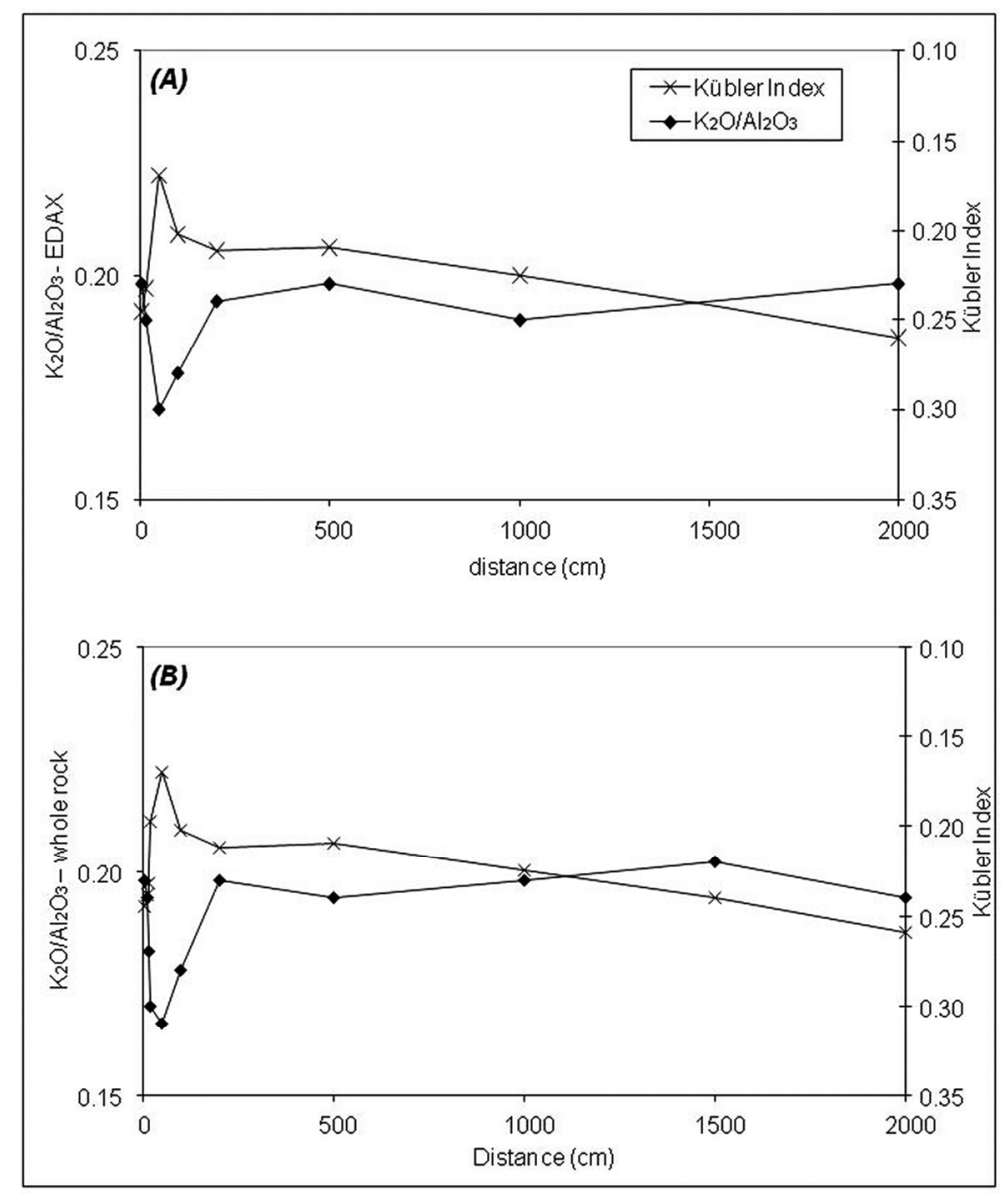

Fig. 9. Relationship between $\mathrm{KI}$ and $\mathrm{K}_{2} \mathrm{O} / \mathrm{Al}_{2} \mathrm{O}_{3}$ vs distance from a $43 \mathrm{~cm}$ wide rhyolite intrusion. A) $\mathrm{KIs}$ and SEM-EDAX data, B) Kübler indices and whole rock elemental data.

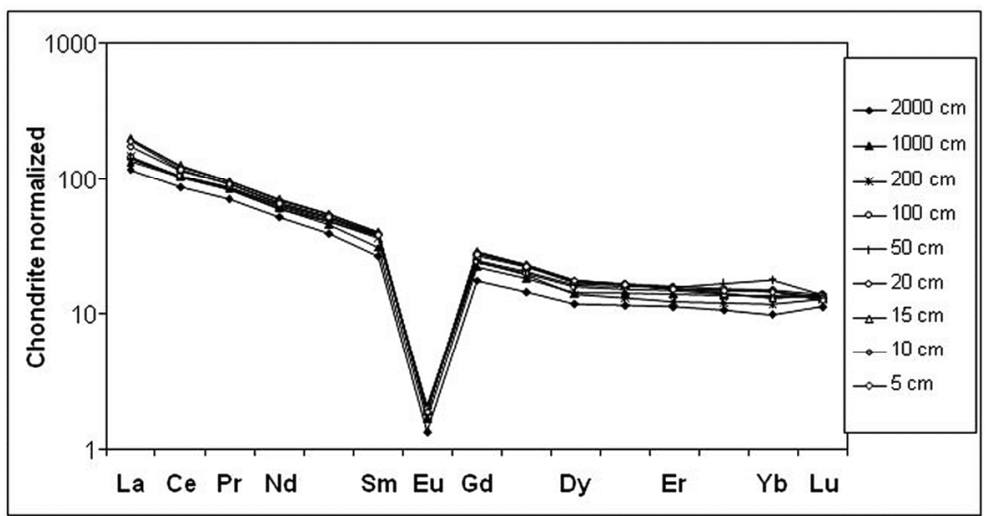

Fig. 10. Chondrite normalized spidergrams for REEs around a $43 \mathrm{~cm}$ wide rhyolite intrusion. 


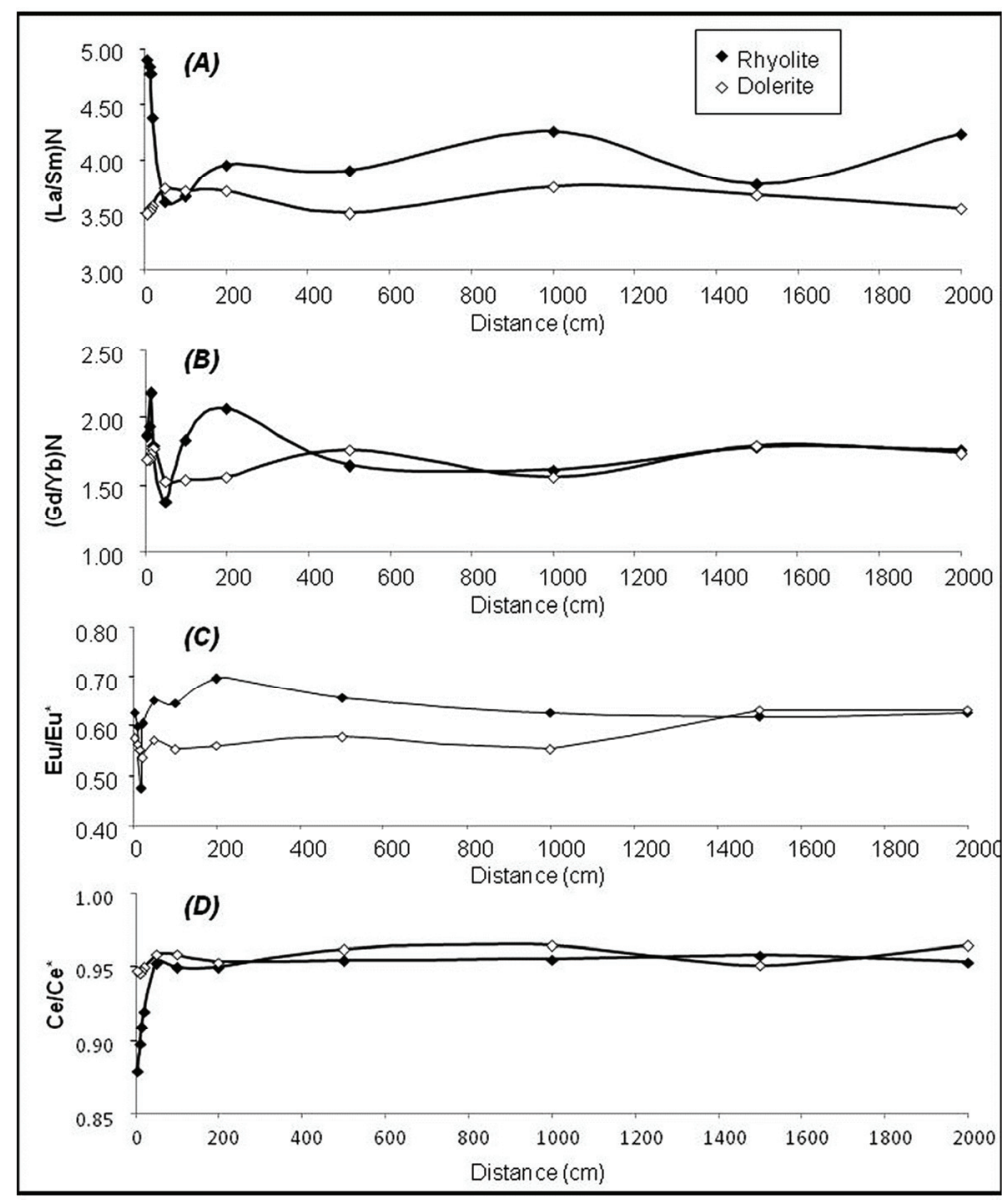

Fig. 11. Variation in a) $\mathrm{La}_{\mathrm{N}} / \mathrm{Sm}_{\mathrm{N}}$, b) $\mathrm{Gd}_{\mathrm{N}} / \mathrm{Yb}_{\mathrm{N}}$, c) $\mathrm{Eu} / \mathrm{Eu}^{*}$, d) Ce/Ce* with distance from a $43 \mathrm{~cm}$ rhyolite intrusion.

\section{Discussion}

The rocks in this area are affected by the Hercynian metamorphism which leaves a regional imprint on the KI, which can be seen increasing from east to west towards the "Hercynian Front" (Diskin 1996).The metamorphic event, which produced the regional variation in KI in the rocks of southeast Waterford, occurred after the emplacement of these intrusions and does not appear to overprint the KI pattern seen around the intrusions.

Higher KI values relative to those in the surrounding mudrocks have previously been recorded in aureoles (Roberts, Merriman 1985), the suggested reason for this was that baked mudrocks resisted later recrystalisation and cleavage formation. The $<2 \mu \mathrm{m}$ assemblages from those baked and spotted pelites frequently included rectorite, corrensite and/or pyrophyllite, none of which were observed in this study. They concluded that these minerals survived because the rocks, already indurated by contact metamorphism from the 
intrusions of up to $3 \mathrm{~km}$ diameter, were unable to develop a penetrative cleavage. The cleavages around intrusions investigated in this study were not noticed to be any less penetrative than elsewhere. As the intrusions seen in this study are considerably smaller than those discussed by Roberts and Merriman (1985), the level of induration of the country rocks may be expected to be lower and rectorite and corrensite have not formed. The intrusions in this case are quite small and often the "retardation" effect is much larger than the intrusion itself, so baking of the surrounding rocks preventing them from developing a penetrative cleavage is not seen as the most likely possibility. The minor intrusions in the study area appear to have little effect on the cleavage which is variable as a whole, ranging from where the most obvious fabric is a bedding plane fissility to where a more penetrative if somewhat undulose cleavage is to be observed in the rocks (a regional variation).

Simple baking of the shales by the igneous intrusions would be unlikely to cause the differences seen between the KIs in the rocks around the rhyolite and dolerite intrusions. The dolerite being formed from a hotter magma would be expected to show a more extensive "aureole". From the point of view of this study, the fundamental differences between these two types of intrusion are temperature and "wetness". Acidic and intermediate magmas may be rich in fluids /volatiles in comparison to basic magmas. The "retardation" seen in the KIs in this study is considered to be related to these fluids /volatiles. While REEs are generally considered to be comparatively immobile, some studies (e.g. Milodowski, Zalasiewicz 1991) have shown that under early diagenetic conditions, REEs, especially the LREEs can be mobilised. Specifically they found that LREEs and MREEs were mobilised during early diagenesis from turbidite units and redeposited largely within adjacent anoxic mud units where immobilisation of REEs were related to the high content of organic material, either fixing the REE directly and/or providing phosphate for coprecipitation of REE phosphate during diagenetic breakdown. In this study, a comparative enrichment in LREEs is seen close to a rhyolite intrusion, with $\mathrm{La}_{N} / \mathrm{Sm}_{\mathrm{N}}$ being high immediately adjacent to the intrusion and returning to regional levels further away. The HREEs and $\mathrm{Eu} / \mathrm{Eu}^{*}$ show more variable patterns possibly reflecting mobilisation of the LREEs. Baking of the rocks would not cause mobilisation of elements, however a fluid passing through the unlithified sediment might. Variations in KI and chemistry are not seen in the dolerites, which are comparatively volatile poor, supporting the "volatiles" hypothesis rather than baking and induration.

How these magmatic volatiles retard the crystallisation of illite is an interesting question. The burial and metamorphic events, which provided the conditions for the formation of the illite, occurred after the rhyolites had been intruded into the shale. Diagenesis may have begun before the intrusion of the last rhyolites, but the effect seen is the same for both the early and later intrusions. Potential causes of the observed effect are that a component of the volatiles, possibly water itself, interfered with normal bonding processes that caused the crystallisation of illite. The problem with this idea is that many of 
the sediments were still wet when the rhyolite was intruded so additional should not affect the growth of illite, nor is it likely to cause such a repeatable pattern.

It is possible that acid fluids from the igneous intrusions in this study might have opened illite layers, with a reversal in trend as the intrusion/sediment contact is approached due to a local increase in $\mathrm{K}^{+}$derived from the intrusion itself as well as a baking effect just at the contact. While $\mathrm{K}^{+}$is seen to mirror the KIs around the rhyolite intrusions there is no evidence of I-S formation, as noted by the Ir values of around 1 and the plotting of the 002 and 003 reflections (Fig. 4). Fleet (1984) suggested that a decrease in $\mathrm{pH}$ resulting in acidic conditions may cause REE mobility, changes in $\mathrm{pH}$ may affect $\mathrm{Ce}$ and Eu because of their ability to exist in different oxidation states. Here we see unexpected variations in REE patterns around rhyolite intrusions which are not mirrored in the patterns around dolerite intrusions (Fig. 9) indicating the likelihood of variably acidic conditions causing remobilisation of REEs in the clays.

While this may explain some of the changes seen, it does not account for the higher KIs and the chemistries seen around the rhyolite intrusions. This zone would have en elevated $\mathrm{K}_{2} \mathrm{O}$, while acid leaching would tend to lower the $\mathrm{K}_{2} \mathrm{O}$. It can be speculated that the hydrothermal event related to the intrusion of the rhyolite resulted in crystallization of fine grained illite from fluids dominated by $\mathrm{K}_{2} \mathrm{O}$. The data also show that $\mathrm{Na}_{2} \mathrm{O} / \mathrm{Al}_{2} \mathrm{O}_{3}$ is lowest in the high $\mathrm{KI}$ zone (opposite to $\mathrm{K}_{2} \mathrm{O} / \mathrm{Al}_{2} \mathrm{O}_{3}$ ). The observed pattern could be explained by assuming that the diagenetic / metamorphic illitization involved fluids higher in $\mathrm{Na}$ and most probably in $\mathrm{NH}_{4}$ (not measured here) and the incorporation of these cations in diagenetic illite would explain the lower $\mathrm{K}_{2} \mathrm{O}$ corresponding to lower $\mathrm{KI}$. This could be verified by K-Ar dating (beyond the scope of the present work), as the illites from the elevated KI zone would in this case be older. Dolerites are not associated with a hydrothermal event or fluids, which explains why no anomalies are seen around them.

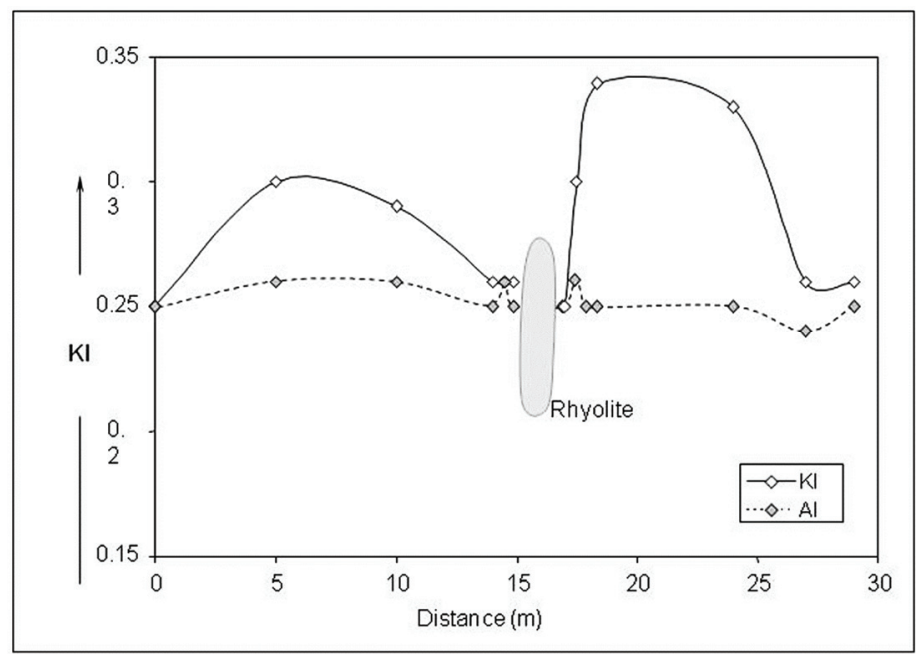

Fig. 12. Plot showing AI compared to $\mathrm{KI}$ around a rhyolitic intrusion. 
All the chlorite crystallinity data for this area were plotted against the corresponding white mica crystallinity data to see if chlorite crystallinity was similarly affected as other authors (e.g. Àrkai 1991) had indicated linear relationships. Here, the KIs and AIs corresponded well regionally, however AIs do not seem to mirror the effect seen in KIs around the igneous intrusion (Fig. 12). If acidic fluids were active around the rhyolitic intrusions, chlorite would be attacked as it is much less resistant to acid attack than illite. It is quite likely that the chlorite did not exist at the time of the emplacement of the intrusions and being of diagenetic/metamorphic in origin could not be affected by the earlier hydrothermal event. This would also explain why the KIs and the AIs, where present, correspond on a regional scale as they are related to the same event.

\section{Conclusions}

Rhyolitic intrusions have an apparently marked effect on the KI of the shale into which they are intruded, seen as an aureole or zone with low KI, possibly caused by acid leaching of the illite crystallites by the volatiles derived from the acidic rhyolite. This was not observed around doleritic intrusions where only the expected baking zone was noted. Chlorite crystallinities do not mirror this effect indicating that hydrothermal fluids interacted with the sediments before the regional diagenetic / metamorphic event too place. The results of this study would indicate that when almost syndepositional rhyolites are encountered in an area where KI is to be measured that KI surveys around some of the intrusions are carried out as well as the regional study so that the effects of any rhyolite intrusion present can be taken into account. While the case considered here considers almost syndepositional rhyolites and dolerites, future studies should consider whether this kind of anomaly is seen associated with intrusions into lithified sediments.

Acknowledgements. The authors would like to thank Professors C.J. Stillman and C.H. Holland of Trinity College Dublin for their assistance, enthusiasm and encouragement, as well as the use of the facilities. The authors are grateful to W. Crawford Elliott, and two anonymous reviewers for helpful comments which have greatly improved the manuscript. Special thanks to P. Diskin without whom much of this work could not have been carried out.

\section{References}

Àrkai, P. (1991). Chlorite crystallinity: an empirical approach and correlation with illite crystallinity, coal rank and mineral facies as exemplified by Palaeozoic and Mesozoic rocks of northwest Hungary. Journal of Metamorphic Geology, 9, 723-734.

Àrkai, P., \& Sadek Ghabrial, D. (1997). Chlorite Crystallinity as an indicator of metamorphic grade of low temperature meta-igneous rocks: a case study from the Bukk Mountains, Northeast Hungary. Clay Minerals, 32, 205-222.

Battaglia, S., Leoni, L., \& Sartori, F. (2004). The Kubler Index in Late Diagenetic to low-grade metamorphic pelites: a critical comparison of data from $10 \AA \AA$ and $5 \AA$ peaks. Clays and Clay Minerals, 56, 85-105. 
Bisevac, V., Balen, D., Tibljas, D., \& Spanic, D. (2009). Preliminary results on degree of thermal alteration recorded in the eastern part of Mt. Papuk, Slavonia, Croatia. Geologia Croatia, 62, 63-72.

Blackmore, R.H. (1995). Low-grade metamorphism in the Upper Palaeozoic Munster Basin, southern Ireland. Irish Journal of Earth Sciences, 14, 115-133.

Breitschmid, A. (1982). Diagenese und schwache Metamorphose in den sedimentaren Abfolgen der Zentralschweizer Alpen Vierwaldstatter See, Urirotstock). Ecolgae geologica Helvetica, 75, 331-380.

Crouzet , C., Dunkl, I., Árkai, P., Balogh, K., \& Appel, E. (2007). Temperature and age constraints on the metamorphism of the Tethyan Himalaya in Central Nepal: A multidisciplinary approach. Journal of Asian Earth Sciences, 30, 113-130.

Diskin, S. (1996). Low grade metamorphism of the Upper Ordovician Rocks of Southeast Waterford. Unpublished MSc Thesis, University of Dublin, Trinity College.

Downes, K. (1974). The geology and geochemistry of the Ordovician volcanics of Co. Waterford. Unpublished PhD Thesis, University of Dublin, Trinity College.

Dunoyer de Segonzac, G., Ferrero, J., \& Kubler, B. (1968). Sur la cristallinite de L'illite dans la diagenese et l'anchimetamorphisme. Sedimentology, 10, 137-143.

Eberl, D.D., \& Velde, B. (1989). Beyond the Kubler Index. Clay Minerals, 24, 571-577.

Fleet A.J. (1984). Aqueous and sedimentary geochemistry of the rare earth elements. In P. Henderson (Ed.), Rare Earth Element Geochemistry (pp. 343-373). Amsterdam: Elsevier,

Frey, M. (1987). Low Temperature Metamorphism. Glasgow: Blackie and Son.

Fritz, W.J., \& Stillman, C.J. (1996). A subaqueous welded tuff from the Ordovician of County Waterford, Ireland. Journal of Volcanology and Geothermal Research, 70, 91-106

Gardiner, P.R.R. (1974). The Duncannon Group: An upper Ordovician unit in southwest County Waterford. Geological Survey of Ireland Bulletin, 1, 47-52.

Gibbs, R.J. (1965). Error due to segregation in quantitative clay-mineral X-ray diffraction mounting techniques. American Mineralogist, 50, 741-751.

Guggenheim, S., Bain, D.C., Bergaya, F., Brigatti, M.F., Drits, V.A., Eberl, D.D., Formoso, M.L.L., Galan, E., Merriman, R.J., Peacor, D.R., Stanjek, H., \& Watanabe, T. (2002). Report of the Association Internationale pour 1'Etude des Argiles (AIPEA) Nomenclature committee for 2001: Order, disorder and crystallinity in phyllosilicates and the use of the 'Crystallinity Index'. Clay Minerals, 37, 389-393

Jaboyedoff, M ., Bussy, F., Kubler, B., \& Thelin, Ph. (2001) Illite "Crystallinity" Revisited. Clays and Clay Minerals, 49(2), 156-167.

Kim, J.C., Lee, Y.I., \& Hisada, K. (2007). Depositional and compositional controls on sandstone diagenesis, the Tetori Group (Middle Jurassic-Early Cretaceous), central Japan. Sedimentary Geology, 195, 183-202

Kisch, H.J. (1987). Correlation between indicators of very low-grade metamorphism. In M. Frey (Ed.), Low Temperature Metamorphism (pp. 227-300). Glasow: Blackie and Son.

Kisch, H.J. (1991). Illite crystallinity: recommendations on sample preparation, X-ray diffraction settings and interlaboratory samples. Journal of Metamorphic Geology, 9, 665-670.

Kübler, B. (1967). La cristallinité de l'illite et zones tout a fait superieures du metamorphisme. In: Etages tectonique, Colloque de Neuchatel 1966 (pp. 105-121). A la Baconniere, Neuchatel, Suisse.

Kübler, B. (1968). Evaluation quantitative du metamorphisme par la cristallinité de l'illite. Bulletin Centre Recherche Pau-SNPA, 2, 385-397.

Liu, K.W. (2003). Deep-burial diagenesis of the siliciclastic Ordovician Natal Group, South Africa. Sedimentary Geology, 154, 177-189.

Merriman, R.J., Roberts, B., \& Peacor, D.R. (1990). A transmission electron microscope study of white-mica crystallite size distribution in a mudstone to slate transitional sequence, North Wales, UK. Contributions to Mineralogy and Petrology, 106, 27-40.

Milodowski, A.E., \& Zalasiewicz, J.A. (1991). Redistribution of rare earth elements during diagenesis of turbidite/hemipelagite mudrock sequences of Llandovery age from central Wales. In A.C. Morton, S.P. Todd, \& P.D.W. Haughton, (Eds.), Developments in Sedimentary Provenance Studies (pp. 101-124). Geological Society, London, Special Publication, 57. 
Nadeau, P.H., \& Reynolds, R.C. (1981). Burial and Contact Metamorphism in the Mancos Shale. Clays and Clay Minerals, 29, 249-259.

Roberts, B., \& Merriman, R.J. (1985). The distinction between Caledonian Burial and regional metamorphism in pelites from North Wale: an analysis of isocryst patterns. Journal of the Geological Society, London, 142, 615-624.

Ruiz Cruz, M.D. (2008). Na-bearing white micas from Triassic rocks of the transition between the Malaguide and Alpujarride Complexes (Beltic Cordillera, Spain). Clays and Clay Minerals, 56, 344-358.

Sleeman, A.G., \& McConnell. B. (1995). Geology of East Cork-Waterford: A geological description of East Cork, Waterford and adjoining parts of Tipperary and Limerick to accompany the bedrock geology 1:100,000 scale map series, Sheet 22, Geology of East Cork-Waterford.

Środoń J. (1984). X-ray powder diffraction identification of illitic materials. Clays \& Clay Minerals 32, 337-349.

Środoń J., \& Eberl D. D. (1984). Illite. In S.W.Bailey (Ed.) Micas. Reviews in Mineralogy 13, (pp. 495-544). Washington, DC: Mineralogical Society of America.

Warr, L.N., \& Rice, A.H.N. (1994). Interlaboratory standardisation and calibration of clay mineral crystallinity and crystallite size data. Journal of Metamorphic Geology, 12, 141-152. 